\title{
Ideology's Operation Mode in Domingo and Canal de Moçambique Newspapers during the Political-military Tension
}

\author{
By Isaías Carlos Fuel \& Sandra Mapilele ${ }^{\dagger}$
}

\begin{abstract}
The Mozambican political system is characterized by several political parties. However, it is important in this article to analyze the expressiveness of the two major parties, which defend their interests and ideas in a quest to gain a favorable social representation. Doing so, they maintain and sustain a relation of dominance. The media are the key instruments in the dissemination of a party's propaganda, because it is through them that ideologies are disseminated to the population. The present research aims to analyze the ideology's operation modes of "Domingo" and "Canal de Moçambique" newspapers in 2013, at the peak of the political-military conflict, which involved Renamo, the opposition party, and the government led by the Frelimo party. The article is based on methodological depth hermeneutics; through a depth hermeneutic tool, the data demonstrate the projection of a meaning which resides in the legitimization of their actions. The discourse is presented in a rational way in order to create certain logic for their arguments. The data, also, illustrated that each party universalizes its interests, that is, the party's interests are presented as interests of the population. Finally, the use of fragmentation was demonstrated through expurgation, where the other is represented as an enemy to the national interests, so the population is called to support the party to fight against the national enemy.
\end{abstract}

Keywords: ideology, discourse, Frelimo, Renamo.

\section{Introduction}

There is no doubt that the media play an important role in building social understanding of everyday communities. They act as an influencer of attitudes, belief, behavior, and of the ways of thinking of a certain community. That is why, bringing the repercussion of the political-military conflict through the different ways in which the media take voice in the interpretation of reality, will give us an understanding of their leading role in this process. This article analyzes the ideology's operation modes of Domingo and Canal de Moçambique newspapers during the political-military tension in Mozambique, in 2013.

This theme, firstly, takes into account the concept of ideology, which according to Thompson (2011, p. 79), refers to "ways in which meaning is mobilized by symbolic forms to serve, establish and sustain relations of domination through a continuous process of production and reception of the symbolic forms". It is important to add to this definition a reflection about the political context in which the political-military tension took place. The socialhistorical context in which the two newspapers report is a central element in order to perceive the discourses constructed with aim to sustain and maintain the

${ }^{*}$ Lecturer \& Researcher, Escola Superior de Jornalismo, Mozambique.

${ }^{\dagger}$ Lecturer \& Researcher, Escola Superior de Jornalismo, Mozambique. 
relations of domination of the two major political parties in Mozambique (Renamo and Frelimo).

Based on the method of depth hermeneutics, a sample of 12 articles of Domingo and Canal de Moçambique newspapers, published in 2013, were analyzed. This analysis was also based on three theoretical approaches on ideology, with the first approach evoking the discussion of Destutt de Tracy and the Bonaparte's perception of ideology. Second, the discussion focuses on the Marxist perception of ideology and Thompson's conception of it. Last, there is an analysis of the modus operandi of ideology within Domingo and Canal de Moçambique newspapers, under the light of Thompson's model.

\section{Theoretical Debate}

\section{Ideology}

The concept of ideology has presented, over time, different facets. Thompson summarizes the different meanings attributed to this concept in two categories: the first category comprises the neutral conceptions of ideology, and the second one includes the negative conceptions. This study explores the second category.

The neutral conception (Thompson, 2011, p. 44) can be visualized within Destutt de Tracy's thinking in 1796. According to Thompson (2011, p. 44), Desttut de Tracy describes ideology as a new project of a new science that aims to systematically analyze ideas and sensations. Thompson (2011, p. 72) says that the neutral conception claims that ideology does not imply developing illusory ideas, misleading or linked to the interest of any particular group. He adds that ideology is only an aspect of social life, like many others and it is not problematic.

The second category is characterized by the critical or negative conceptions of ideology. The starting point was given by Napoleon Bonaparte; he described ideologies as abstract, speculative and divorced from the reality of political power. This way of signifying ideology was embraced by Karl Marx, giving a new tone, which this study assumes. Marx views ideology as an instrument in the hands of the bourgeois class, aiming at manipulating and creating illusion in the proletarian class (Thompson, 2011, p. 54). This position was summarized by Thompson (2011, p. 51), as follows:

"Ideology, in this sense, is a theoretical doctrine and an activity which erroneously looks at ideas as autonomous and effective, and which cannot understand the real conditions and characteristics of socio-historical life".

It is also important to emphasize that, within the debate that Marx brings about ideology, there is the epiphenomenal conception that looks at the dependent and derived ideology of economic conditions, class relations and class production. Thus, ideology is defined as a system of ideas that expresses the interests of the ruling class, so it represents the class relations in an illusory way. Thompson (2011, p. 54) further explains: 
"Ideology expresses the interest of the ruling class, in the sense that the ideas that make up the ideology are the ideas that in a particular historical period articulate the optimistic ambitions, interests, and decisions of the dominant social groups, as they strive to secure and maintain their position of domination. Ideology represents class relations in an illusory way, because these ideas do not accurately represent the nature and relative positions of the interested classes, on the contrary, they misrepresent these relations in a way that favors the interests of the ruling class".

Within Marx's view of ideology, it is important to understand what this author calls the latent meaning. According to Hall (2003, p. 179) "ideology representation systems materialized in practice". These systems are composed of ideas, myths or images, in which men and women live their imaginary relations with the real conditions of existence. This author emphasizes that we must understand the systems of representation as "systems of meanings by which we represent the world for ourselves and for others". Taking Marx's view, Thompson asserts that this system of representation hides and misleads, and that in so doing, it serves to maintain the relations of domination (2011, p. 75).

However, Thompson emphasizes that the symbolic forms are not merely representations serving to conceal or obscure social relations or interests that are constituted fundamentally and essentially at the pre-symbolic level. On the contrary, symbolic forms are continually and creatively implied in the constitution of social relations. It is within this understanding that Thompson conceptualizes ideology in terms of "the ways in which meaning is mobilized by symbolic forms to serve and to establish and sustain relations of domination through a continuous process of production and reception of symbolic forms" (2011, p. 79). So, for Thompson, ideology must be seen as a:

"System of representations that serve to sustain the existing relations of class domination through the orientation of people to the past rather than to the future, or to images and ideals that conceal class relations and deviate from the collective quest for social change".

According to Thompson, the analysis of how the meaning is produced must respect the socio-historical analysis, which means that one must examine the social and historical conditions of the production, circulation and reception of the symbolic forms (2011, p. 34). Within the context, the analysis must take into account the social, political, economic, cultural and historical influences, since knowledge should not be a result of reflection of reality, but a social practices reflection (Hall, 2003, p. 170).

\section{Ideology's Operation}

As a way to understand how the meaning is generated, Thompson developed an instrument, by which it can be objectively perceived how in certain sociohistorical contexts men and women mobilize symbolic forms, in order to maintain 
and sustain the relations of domination. He presents five modes of operation of ideology: dissimulation, unification, fragmentation and reification (Table 1).

Table 1. Ideology's Operation

\begin{tabular}{|l|c|}
\hline \multirow{3}{*}{ Legitimation } & Rationalization \\
\cline { 2 - 2 } & Universalization \\
\cline { 2 - 2 } Dissimulation & Narrativisation \\
\cline { 2 - 2 } & Displacement \\
\cline { 2 - 2 } Unification & Trope (Synecdoche, metonymy, metaphor) \\
\hline \multirow{2}{*}{ Fragmentation } & Standardization \\
\hline \multirow{2}{*}{ Reification } & Symbolization of unity \\
\cline { 2 - 2 } & Differentiation \\
\cline { 2 - 2 } & Expurgation of the other \\
\cline { 2 - 2 } & Naturalization \\
\hline
\end{tabular}

The first ideology's operation mode is Legitimation. According to Thompson, there is legitimation of the discourse when the individual seeks to establish and sustain the ideology through legitimate actions, i.e. seeks to win the confidence of the population with pronouncements that demonstrate authenticity and truthfulness. Legitimation has three grounds: Rationalization, Universalization and Narrativisation.

According to Thompson, Rationalization is characterized by a symbolic construction organized in the form of a logical chain, seeking to sustain and justify the set of ideas, with the aim of persuading its public that their convictions are worthy of support. Universalization is the presentation of individual interests as the interest of all. Narrativisation consists in searching for old stories of success and mobilizing them in the present as a way of perpetuating and making the present situation acceptable.

The second ideology's operation mode is Dissimulation. In dissimulation, the relations of domination can happen and can be sustained through concealment, negation, or obscured in ways that divert the attention of individuals. Dissimulation can be expressed in forms such as Displacement, Euphemization and Trope. Displacement operates when the ideas that are used to refer to a particular subject/object are used to refer to the other, that is, to the positive or negative attributes of that object/subject. The strategy of Euphemism constitutes a symbolic construction with the objective of creating and sustaining actions in order to stimulate a positive appreciation of the ideology presented by the ruling class.

The Trope is a symbolic construction which employs the figurative use of language. Among the integrated strategies, we have: Synecdoche, Metonymy and Metaphor. Concerning synecdoche, Thompson (2011, p. 84) states that this strategy consists in using a term which refers to the whole. While metonymy, consists in the use of a term that takes the place of an attribute, of an adjunct. It is also possible to use a characteristic related to some thing to refer to the thing 
itself, although there is no necessary relation between the term and the thing to which it may refer. Within the trope as strategy, we find metaphor, where some terms are used even though they cannot be applied. Within this strategy individuals can be assigned characteristics that have no relation to them.

Unification is the third ideology's operation mode. In this strategy, ideas are mobilized or constructed to establish a certain unity between individuals or a collective identity, regardless of the differences and divisions that can separate them. Unification is branched into two symbolic forms, namely Standardization and Symbolization of unity.

Standardization is used for the purpose of symbolic exchange when seeking for a national standard language, which helps the creation of a collective identity among the various groups of society. The Symbolization of unity consists in the symbolic construction, with the aim of unification. Within these strategies, ideology is mobilized with the aim of building a collective identity through one or more groups.

In addition to the modes described above, we find Fragmentation, which consists in fragmenting individuals and groups instead of collectively unifying them. By doing so, a given group may be represented as threatening or dangerous, and it becomes legitimate to ban it within society. Within this symbolic construction, we find the differentiation and expurgation of the other. Differentiation is characterized by the ability to create a kind of division between people, for example Renamo and Frelimo in the case of the phenomenon under analysis in this study. The strategy of purging the other constitutes the creation of an enemy, whether internal or external, who is considered dangerous and threatening in the relations of domination.

The last operation's mode corpus of ideology within Thompson's classification is Reification. In Reification, power relations can be created and sustained from the socio-historical occultation of facts; Reification makes a "transitory, historical situation look as if this situation were permanent, natural, and timeless" (Thompson, 2011, p. 87). In this strategy there is an "elimination of the socio-historical character of phenomena" (Thompson, 2011, p. 88). The strategies used are: Naturalization, Externalization and Nominalization/ Passivization. Naturalization consists in presenting as natural a state of things that are socio-historical creations (Da Silva \& Verissimo, 2010, p. 8).

Externalization is a strategy similar to naturalization, where socio-historical phenomena are deprived of their historical character by being presented as permanent, immutable and recurrent. Thompson (2011, p. 88) explains that:

"Customs, traditions and institutions which seem to extend indefinitely in the past direction, so that every trace of their origin is lost and all questioning of their purpose is unimaginable, they acquire a rigidity that cannot be easily broken. They crystallize in social life, and their seemingly a-historical character is reaffirmed through symbolic forms, which, in their construction, as well as in their pure repetition, eternalize the contingent".

Within this mode, we have Nominalization and Passivation. Nominalization occurs when actions become the subject of actions, while Passivation occurs 
when the passive voice is used where agents are described passively. According to Da Silva \& Verissimo (2010, p. 8), "these two strategies are used in politics when addressing audiences in public speaking, on certain issues to the detriment of others".

\section{Problematic}

In order to understand the media's construction of meaning around the political-military crisis, it is important to capture two inseparable dimensions in this process, on one hand the national political scenario, on the other, the evolution of the role that the media have assumed.

\section{Mozambique Media Outlook}

The role played by the media took various dimensions, according to the transformations which took place in the social, political and economic structure in Mozambique. After independency (from 1975 to 1990), we can highlight that media were seen as an advanced instrument in the class struggle in the revolution. It was underlined during the First National Seminar on Information, from September $12^{\text {th }}$ to $15^{\text {th }}, 1977$. In the words of Samora Machel, the first president of independent Mozambique, as cited in Chichava and Pohlmann (2010, p. 128), the first seminar emphasized that:

"...The Party must pay particular attention to the political framework of the journalists. In this sense, we will intensify the implementation of the structures of the Party within the newsroom..."

and also that:

"... The journalists [should] be aware that they occupy a position of combatant on the ideological front of the struggle of the working masses, so they must fully assume the interests and aspirations of the workers and peasants". (Chichava \& Pohlmann, 2010, p. 128)

In this vein, the Notícias, Diário's Newspapers, Radio Moçambique and the Televisão de Moçambique that appears later, just to mention a few examples, were under the Frelimo government control. It is within this scenario that the media operated, because Frelimo leadership used the media as "an important instrument to convey the ideals of the new regime and discourage or control hostile sectors and consolidate national unity" (Chichava \& Pohlmann, 2010, p. 128).

The second scenario has its foundations at the end of the civil war, which ended with the signing of the general peace agreements in Rome, on October $4^{\text {th }}$, 1992. As a consequence of the end of the conflict, Mozambique adopted a democratic and multi-party constitution that was reviewed in 2004, counting among many other advantages, the statement of freedom of speech and the press, 
and the right to information as a fundamental right of Mozambican citizens (Constitution of the Republic of Mozambique, 1990).

According to Joanguete (2013, p. 98), despite the Mozambican constitution establishing freedom, access to information and the press, "there is still a lack of legislation that would be more detailed and compatible with the current reality, and compatible with the great changes in the media sector". As a result of this deficit, the author states that a force was exercised by journalists and professional associations, so that a legal instrument regulating social communication is approved. It is within this scope that Law 18/1991, known as the press law, and the law on the right to information, Law 34/2014, were approved. Law 18/1991 establishes the rights and duties of the media, to indicate the chair of the Higher Council of Social Communication (CSCS) (Joanguete, 2013, p. 98). While the law on the right to information, Law 34/2014:

"...Regulates the exercise of the right to information, the materialization of the constitutional principle of the permanent democratic participation of citizens in public life and the guarantee of the fundamental rights..."

The same law, in Article 13, underlines that:

"The exercise of the right to information includes the right to request, seek, consult, receive and disclose information of public interest held by the entities defined in article 3 of the Law".

With Regard to censorship, the mother law prohibits censorship in relation to the exercise of freedom of speech and in relation to the right to information, as prescribed in article 48, paragraph 2:

"The exercise of freedom of speech, which includes the right to disseminate one's own thinking by all legal means, and the exercise of the right to information cannot be limited by censorship..."

According to Joanguete (2013, p. 99), while the law establishes zero tolerance against censorship, studies show that the government authorities exercise control over community radio, newspapers, radios, public and private television. In the same path, Xadreque ${ }^{1}$ (former Editor of the newspaper Público), speaking of political interference in the media, says:

"In the private newspapers, when there is a critical situation, they use the tactic of buying the newspaper and becoming partner; this has happened to several newspapers. As partners of the newspaper, they hire people of their trust to control the contents. They remove all enemy, in order to accommodate their individual and party interests. Even the first page of the newspaper is controlled by them (Xadreque, interview 2014)".

\footnotetext{
${ }^{1}$ Interview held in October 2014, in his office in Maputo.
} 
A study carried out in 2017 by MISA Mozambique, in order to determine the level of openness of private and public institutions in Mozambique, revealed that an attitude of fear and secrecy persists in the provision of information of public interest.

\section{Political Scenario in Mozambican}

Mozambique shares borders with Tanzania in the north; in the South, with South Africa and Swaziland; in the West, with Zimbabwe, Zambia and Malawi; in the East, it is bathed by the Indian Ocean. It occupies an area of $799,380 \mathrm{~km}^{2}$, divided administratively in 10 provinces: Maputo; Gaza; Inhambane; Sofala; Zambézia; Nampula; Cabo Delgado; Niassa; Manica and Tete respectively. From the point of view of identity, Mozambique is made up of several tribes that are worth mentioning: the Nyau, Scenes, Shonas, Makuas, Makondes, Tongas, Tsongas and Copi.

With regard to the political landscape, Mozambique has a political scenario based on a decade of liberation war that culminated in the victory of the Liberation Front of Mozambique (FRELIMO) and consequently the signing of the Lusaka agreements in Zambia in 1974, which followed the creation of a transitional government. The proclamation of independence came in June 1975, when Frelimo assumed power and declared at the third congress, in 1977, that Mozambique should be a one-party state with a Marxist orientation.

The internal cleavages within the Liberation Front of Mozambique (Brito et al., 2003, p. 21) made room for a post-independence war in 1976, which was seen by some as a "destabilization war" and by others as "civil war". Brito et al. (2003, p. 22) affirm that "the extremely centralized character of the Mozambican State, the access to the economic and power resources of the southern elite and the cleavages between urban and rural" are at the root of political dissatisfaction.

The war that has waged Mozambique to develop in order to build a better quality of life for its inhabitants, lasted 16 years and, as a result of long and intense talks between the government and Renamo, the peace was reached in the early 90s. According to Brito et al. (2003, p. 20), the starting point of the negotiations was in 1983, with the signing of the Nkomati agreement, which provided that both the government of Mozambique and the South African government would not lodge in their territory and support the activities of the opposition movements. Therefore, they began negotiating with Renamo, and the first attempts aimed to offer "an amnesty and integration of Renamo's members in Mozambican society" (Brito et al., 2003, p. 22).

Although the first talks between Frelimo and Renamo did not go as planned, Frelimo did not stop and other strategies were implemented. As a result, in the late 1980s, Frelimo abandoned the Marxist ideology and reviewed the constitution, and Mozambique changed from Popular Republic into the Republic of Mozambique. With the support of the Catholic Church and the international community (Sant'Egidio), negotiations between Frelimo and Renamo became possible, which culminated in signing the Peace Agreement on October $4^{\text {th }}, 1992$. Then, a new 
constitution created the conditions for the first multiparty elections in 1994, where the Frelimo party and its candidate won.

The permanent tension of distrust between Frelimo and Renamo was growing stronger day by day, because in all elections, Renamo would contest the results, alleging fraud and lack of transparency in the scrutiny. Beyond these motivations for tension, Brito et al. (2003, p. 55) state that Frelimo party's inconsistent policy, which does little to facilitate the integration of Renamo's leaders in economic and institutional life, undermines reconciliation in Mozambique.

The Renamo's dissatisfaction grows day-after-day, and the complaints take the direction of the lack of access to the institutions of the State, the Armed Forces and the National Commission of Elections (CNE). As a result of noncompliance with the demands, in 2009, the Renamo leader Afonso Dhlakama, after being defeated by Armando Guebuza, he threatened to restart the war. Years later, he settled in Sadjumdjira, where he began training veterans as a way to require a new political status in Mozambique.

The peak of the tension between Frelimo and Renamo was when the Renamo leader left Nampula to live in Sadjumdjira, where negotiations between the government and Renamo began. In these negotiations, two important issues were discussed: the question of greater representation in the Armed Forces and the revision of the electoral system. These negotiations failed and, as a result, on October $21^{\text {st }}, 2013$, the Mozambican defense forces attacked the residence of the Renamo's leader. In addition to this attack, there was a wave of attacks mainly to the police station and murders of members of both parties (Canal de Moçambique, 2013).

In the above described scenario, the media played their part in communicating the picture of the evolution of the political-military conflict and its impact, which reverberated throughout the national territory. The leading role of the two newspapers is the subject of this analysis: the extent to which they seek to signify the political-military events during the course of the conflict, in the year 2013. We take this stance believing, as other media scholars say, that media not only inform, educate and entertain; they also play a role in disseminating symbolic systems as a part of the state's ideological apparatus (Althusser, 1970, p.44). Through these established relations of domination, the question we raise is the following: how did the two newspapers portray the political-military period in 2013? We respond to this question below.

\section{Data Analysis}

The examination of ideology's operation modes in Domingo and Canal de Moçambique newspapers in relation to military hostilities was based on a deep hermeneutic analysis. According to Thompson (2011, p. 360), "the study of the ideology is based on the significant symbolic construction, susceptible of interpretations taking into account social and historical contexts, structured internally in different ways." Thompson (2011, p. 361) argues that interpretation/ reinterpretation takes into account a movement of synthesis of a creative 
construction of possible meanings mobilized within the political-military context for example.

At this stage, Thompson's model was used to investigate the publications of the Domingo and Canal de Moçambique newspapers during the intense period of the political-military conflict, seeking to understand how they mobilized ideologically to maintain and sustain relations of domination in relation to the political position of each media body.

The data analyzed below comes from the analysis of 10 reports, 1 editorial and 1 opinion, selected from the Canal de Moçambique and Domingo's newspapers. Regarding the Domingo newspaper, the following have been analyzed: a) news written on April $7^{\text {th }}, 2013$, page 4, entitled "Renamo não pode passar a vida a assustar o povo" (Renamo cannot spend his life scaring the people); b) news written on April 21 ${ }^{\text {st }}, 2013$, page 6, entitled "Diálogo não pode pôr em causa a Constituição" (Dialogue cannot call into question the Constitution); c) news written on May 5 $5^{\text {th }}$, 2013, page 3, entitled "Bissopo envenena com discursos incendiários" (Bissopo poisoned with incendiary speeches); d) news written on June $30^{\text {th }}$, 2013, page 4, entitled "Incidentes de Muxúnguè não devem desestabilizar a paz (The incidents of Muxúnguè should not destabilize peace)"; e) news written on July $7^{\text {th }}$, 2013, page 25 , entitled "Há muito desemprego e não temos investimentos" (There is a lot of unemployment and we do not have investments); and finally, f) news written on October $27^{\text {th }}, 2013$, page 8, entitled "Actuação Legítima das Forças Armadas" (Legitimate performance of the Armed Forces).

While Canal de Moçambique's newspaper was analyzed through the following articles: a) news written on July $10^{\text {th }}, 2013$, page 2, entitled "Apertado o cerco à Dhlakama" (The siege of Dhlakama); b) editorial written on July $10^{\text {th }}$, 2013, page 9, entitled "A paz pode estar por um fio" (Peace can be hanging by a thread); c) news written on July $31^{\text {st }}, 2013$, page 16 , entitled "Dhlakama dá mais uma semana para produção de resultados" (Dhlakama gives another week to produce results); d) the opinion letter written on September $11^{\text {th }}, 2013$, page 10, entitled "Queremos paz no nosso seio" (We want peace in our bosom); e) news written on November $6^{\text {th }}, 2013$, page 2, entitled "Conflito armando intensifica-se na região centro" (Armed conflict intensifies in the center region); and finally f) news written on November $27^{\text {th }}, 2013$, page 5, entitled "Dhlakama não pode mandar parar com os ataques" (Dhlakama cannot stop the attacks).

This analysis proceeded in two stages. In the first stage, we will present the ideological mobilization carried out by Domingo's newspaper and the Canal de Moçambique newspapers.

\section{Domingo Newspaper}

\section{a) Legitimation.}

Rationalization. The news written on October $27^{\text {th }}, 2013$, page 8 , use terms seeking to establish cause and effect, to stimulate a need for action in order to attack Sadjumdjira. The news described the attack as legal, as a national 
imperative and as if there were no alternative ways to deal with Renamo. This statement is underlined by the lawyer Pedro Macaringue, in the following terms:

"I do not see any unconstitutionality in this action. Any country that values itself and which has a duty to guarantee the tranquility of its people, and above all the physical integrity of its citizens, could not continue to watch impatiently the movement of the so-called security of the Renamo leader".

Along the same lines, João Roque Goncalves, Lawyer, stated that:

"The Mozambican State can legitimately pursue and dismantle any illegal force in the country. Any armed group that has constituted itself outside the laws must be dismantled, which means that the State does nothing else but complying with what is legislated, which is to destroy, to dismantle a hiding place that was used for the planning of Instability in the central region of the country".

These chains of arguments that legitimize an attack on the Renamo headquarters, ignored the real causes of the Renamo leader's withdrawal to settle in Sadjumdjira as underlined by Brito et al. (2003, p. 55), stating that the Frelimo party's inconsistent policy, which does little to facilitate the integration of Renamo's leaders into the economic and institutional life, undermines reconciliation in Mozambique. It is also important to emphasize that eliminating Renamo has a central meaning for the party of the day, because this is the only party that calls into question the maintenance of Frelimo in power, thus, ending it is a passport for the Frelimo elite to hold for long in power.

\section{b) Universalization.}

"I've been in Rome for two years and I've had patience. All the people must realize that it is not someone who acts like the way we would like him to act. A person who uses the people as his shield, threatens and kills the population, can imagine the complexity of the dialogue" (June $30^{\text {th }}, 2013$, Domingo, p. 4).

The use of the word "People" is called here to demonstrate that the attack on Sadjumdjira is in the interest of the Mozambican people, because the Mozambicans are dealing with an individual who is not open to dialogue; as Thompson (2011, p. 87) asserts, universalization as an ideological mode of operation, consists in presenting the individual or group interests as if they were collective. The mark of universalization as an ideological form is described as follows (Sixpence, 2013, p.6):

"We talk about the need to establish dialogue. But note: the greater dialogue that the Mozambicans had in the recent years was the one that ended the war. That is when the Mozambicans said no to war".

The fact that the author uses the word "Mozambicans" brings us to the idea that the discussion in Rome involved all Mozambicans. Thus, if they were involved, then they are aware of every process, so bringing this debate is a 
waste of time. This strategy may be fallacious, because the current scenario is a result of non-compliance with some dialogue in Rome.

With regard to the Universalization and Expurgation, the editorial of Domingo, May $5^{\text {th }}, 2013$ underlines:

"We, the Mozambicans, are united in peace and we will always respect dialogue and political tolerance. However, we will not sell our character at any price. We are a state of law and we have a constitution by which we govern. Renamo's constant appeals for foreign mediation reveal its unfocused nature".

In this citation, the ideas of Frelimo's party are presented as being in the interest of all, and Renamo is presented as the enemy of Mozambique's interests. However, it is important to underline that there is a tendency in this text to confuse Frelimo with the State, which takes us back to the one party era, lasting from 1975 to 1990. It is also worth noting that history has shown that, although it is said aloud that the Mozambicans can solve their own problems, it seems that some people, even if you play the drums, will not listen, like Renamo did.

\section{c) Unification.}

The Frelimo's ideology is also operated through the Unification mode. It is through the standardization of language that this speech is written on April $21^{\text {st }}, 2013$, page 6 :

"The calls for peacekeeping, reinforced by national unity and dialogue among all the living forces of the Mozambican society, have been highlighted in this edition of the Open and Inclusive Presidency".

The strategy of standardizing symbolic forms in order to have a national character, establishes a certain unity between individuals or a collective identity, regardless of the differences and divisions that can separate them. This helps in the creation of a collective identity between the various groups of the society. Thus, the use of the terms national unity, open and inclusive Presidency, aim to create a symbolic form where all are presented as equal and enjoy the same rights.

\section{d) Dissimulation.}

The emphasized statements of two Lawyers in Domingo newspaper, dated on October $27^{\text {th }}, 2013$, page 8 , "to guarantee tranquility and security" and "instability planning in the central region of the country" take us to Euphemization. According to Thompson, this strategy consists of a symbolic construction with the aim to create and sustain actions which stimulate a positive valorization of ideologies. This means that actions like beating, killing and destroying goods can be described as a way of restoring order. Thus, the authors describe the FIR's action as an action to guarantee tranquility, security and stability in the region. 


\section{e) Fragmentation.}

Differentiation. Fragmentation occurs through differentiation. It happens when the other is described as different, who has characteristics that do not fit with the others, and so he/she must be removed or eliminated. This strategy is demonstrated by the following quotation (Sixpence, 2013, p.8):

"It is unfortunate that there are certain Mozambicans who care to see the climate of war reinstalled in our country, instead of gathering their energy and strength to improve, to stop the poverty and all these start with each one".

Sixpence adds what the former President states (2013, p. 8):

"...Renamo and its leader, Afonso Dhlakama, have many difficulties in adapting to the rules of democratic coexistence and, above all, to integrate in a society where peace reigns, not the arms".

Looking at the two quotes, Renamo's representation is negative, meaning that this party does not deserve to act in the Mozambican political scene, where people live in peace. This strategy separates individuals based on their thinking and the colors of their party. In this way, being member of Frelimo means pro peace, while being member of the opposite party means pro war. Looking at Renamo as the only warmonger is fallacious. Because to not let others develop socially, economically and politically, is another form of war, says Da Silva and Verissimo (2010).

Another strategy used by the newspaper, within the mode of fragmentation, is the expurgation of the other. The expurgation of the other consists in creating the other as an enemy, whether internal or external, considered dangerous and threatening. This strategy is exemplified in the following paragraph: "Renamo cannot spend its life scaring the people". It can also be seen in the following passage: "The Mozambican people cannot live permanently frightened by the threats of Afonso Dhlakama's party". This can also be seen in the following lines (Domingo, July 7th, 2013, page 25): "Due to the presence of the Renamo armed men accompanied by their leader, investors felt threatened and decided not to continue investing here".

Looking at the citations above, the Renamo party is represented as the internal enemy of the Mozambique's people. This party is against development. In this way, it is targeted to be eliminated and all individuals are called to join, in order to displace it.

\section{Canal de Moçambique Newspaper}

\section{a) Legitimation.}

Rationalization. The news published on November $27^{\text {th }}, 2013$, written by Bernardo Álvaro, in the Canal de Moçambique newspaper, are quoting Renamo's Secretary General, Manuel Bissopo: 
"I think it is foolish to wonder whether the president can or cannot order his men to stop the attacks, because the president is the person being offended and his men know that their father is being offended, so they are doing what is necessary to be done in order to protect their father".

In the same path, the Canal de Moçambique newspaper published on Wednesday, November $6^{\text {th }}, 2013$, reports:

"Contrary to the intention of the dialogue that has been verbalized, the government ordered the troops to attack and occupy the residence of the leader of RENAMO, in the city of Beira, the headquarters of RENAMO. Last week, without a judicial mandate, although it is said that later appeared a mandate of a judge, the Defense Armed Forces of Mozambique and the FIR searched the RENAMO headquarters for arms, but no instruments of war were found in any of the facilities".

The comment that Renamo's men did what they could since their father was being offended, demonstrates the use of rationalization, to legitimize the continuity of Renamo's actions. In doing so, it is implied that Renamo must be supported because it is acting in self-defense. Here, the Mozambicans are called to support the Renamist cause, because they are facing an injustice against the leader.

\section{b) Fragmentation.}

Expurgation. The issue of November $7^{\text {th }}, 2013$ of the Canal de Moçambique newspaper reports:

"...Dhlakama guaranteed that, as from that day, both parties should stop appealing to the military. Unfortunately, in the same day we suffered an attack. October $21^{\mathrm{st}}$ ended with a bombshell attack against his life".

The reporter presents Dhlakama as a man of peace, which brings us to differentiation, that seeks to emphasize certain characteristics. In doing so, we are led to expurgation, which consists in presenting the other as the enemy. Dhlakama is presented as a man of peace, while Emílio Guebuza is described as a warmonger, as dangerous and as an enemy of peace, who must be purged from leadership.

The use of the expurgation as an ideological strategy can be illustrated by the following phrase: "15 days have passed since the government troops attacked Sadjumdjira in an unsuccessful attempt to kill or capture the Renamo's leader, Afonso Dhlakama..." (Canal de Moçambique, 2013, p. 2). In the same way, an article written by Ivone Soares, on September $11^{\text {th }}, 2013$, underlines:

"Frelimo has now invented new ways to sow mourning in Mozambican's families in the central region of Mozambique. The esteemed reader should be reminded that, recently, RENAMO reported at press conferences that the Frelimo government ordered the PRM, FIR and FADM to walk from house to house to hunt and execute their demobilized members after the Muxúnguè's events". 
These citations present the President Emilio Guebuza and Frelimo as the enemy, who are killing innocent people, and the people is called to fight against them.

\section{c) Universalization.}

Another ideological tool that Canal de Moçambique newspaper uses is universalization, which consists in presenting the individual or group interests as if they belonged to everyone. On July 31 $3{ }^{\mathrm{st}}$, 2013, the Canal de Moçambique newspaper quoted Dhlakama: "Guebuza is playing with the people, because this country does not belong to him or to José Pacheco, who represents the government in these talks". The use of Universalization can also be seen in another passage from the editorial of July $10^{\text {th }}, 2013$, page 9:

"[Renamo's soldiers] did not attack on the National Road again, [...] out of respect for society, Dhlakama and his commanders, in the last twenty years, have been able to respect the Rome's commitment, despite all the offenses, the vexations, many deaths of the party's members, the destruction of many of the party's headquarters and so many flags torn ".

The people are called here to understand that the Dhlakama's struggle does not defend his personal interests but the interests of the Mozambicans, because Renamo values the society's prosperity.

\section{d) Metaphor.}

The use of metaphor as an ideological element consists in the use of one term taking the place of another, even without any direct connection between them. This strategy can be seen in an article of July $10^{\text {th }}, 2013$, page 2 , in the subtitle, by Timóteo and Veloso, in the Canal de Moçambique newspaper, where a Dhlakama's statement is reported:

"If I leave Maputo and the Frelimo's parakeets approach a few kilometers more, they will be shot. This will be the end of peace in Mozambique, I guarantee you. It will be generalized in all the eleven provinces".

Characterizing the Government's forces as parakeets makes a very interesting comparison, and presents Frelimo as an irresponsible party leading inexperienced and innocent young citizens to war, where they will be unnecessarily killed.

\section{Conclusion}

It is clear to the present research that, according to Thompson's propositions, discourses are not ideological on their own, but they are dependent on the contexts; they depend on how they receive the differentiated symbolic forms, which translate them and give them meanings. Hence, in this research, an effort is 
made to present a reflection that intends to highlight the different ways in which the newspapers Domingo and Canal de Moçambique represented Frelimo and Renamo, with a view to maintaining asymmetric relations of domination in the politico-military context. The insistence on the use of rationalization, expurgation, dissimulation, metaphor and the universalization of their interests by the actors in this conflict, are marks of this domination.

The significance of the newspapers Domingo and Canal de Moçambique in relation to the actions of the Frelimo and Renamo parties in the case of the politico-military conflict, is linked to the maintenance and support of them in power. This occurs through the dissemination of symbolic discourses that start from the legitimation of their actions, and, in the same path, they seek to universalize their own interests and conclude in the presentation of the opposite party as an enemy for the national interests.

\section{References}

Althusser, L. (1970). Ideologia e aparelhos ideológicos de estado (Ideology and ideological state apparatuses). Retrieved from https://bit.ly/2TvAB1b.

Brito, L., Francisco, A., Pereira, J.C.G., Rosario, D. (2003). Moçambique 2003: Uma avaliação do potencial de conflito (Mozambique 2003: An assessment of the potential for conflict). Retrieved from https://bit.ly/2CQmPB0.

Canal de Moçambique (2013, October 30). Editorial: Conflito Arma(n)do (armed conflict). P. 6.

Chichava S., \& Pohlmann, J. (2010). Uma breve análise da imprensa moçambicana (A brief analysis of the Mozambican press). Retrieved from https://bit.ly/2CSLy7H.

Constitution of the Republic of Mozambique, 1990. Retrieved from https://publicofficialsfinancialdisclosure.worldbank.org/sites/fdl/files/assets/lawlibrary-files/Mozambique_Constitution_1990_\%28as\%20amended\%29_pt.pdf.

Da Silva, F. O., Verissimo, F. da Silva (2010). Análise dos Modos de Operação da Ideologia Política do Partido dos Trabalhadores (Modes of Operation of the Political Ideology of the Workers' Part). Retrieved from https://bit.ly/2Ay6BuA.

Hall, S. (2003). Da diáspora: Identidades e mediações culturais (Diaspora: Cultural identities and mediations). Retrieved 03 october 2018 from https://bit.ly/2QqAdiJ.

Joanguete, C. (2013). As mudanças para o jornalismo digital na imprensa pública e privada Moçambicana: estudo comparativo dos jornais Notícias e a Verdade (The changes for digital journalism in the Mozambican public and private press: a comparative study of Noticias e Verdade's Newspapers). Retrieved from http://hdl.handle.net/1822/28789.

Misa Mocambique. (2017). Instituições Abertas e Fechadas: Relatorio de analise sobre o nível da implementação da Lei do Direito à informação em Mocambique ${ }^{1}$. Retrieved from http://www.misa.org.mz/index.php/destaques/noticias/17-misa-mocambiquelanca-relatorio-so bre-as-instituicoes-publicas-abertas-e-fechadas.

Sixpence, J. (2013). Diálogo não pode pôr em causa a Constituição (Dialogue can not call into question the Constitution). Domingo pp. 6-8.

Soares, I. (2013). Queremos paz no nosso seio (We want peace in our bosom). Canal de Moçambique p. 10.

Timóteo, A., \& Veloso, F. (2013). Apertado cerco a Dhlakama: Entrada de Militantes e viatura está a ser impedido, desde esta terça-feira, por forças governamentais, no 
controlo da Vila da Gorogosa, na estrada para "cavalo" (Closed siege to Dhlakama: Militants and vehicle entrance is being blocked, from this Tuesday, by government forces, in control of Vila da Gorogosa, on the road to "horse"). Canal de Moçambique p. 2.

Thompson, J. B. (2011). Ideologia e cultura moderna: teoria social crítica na era dos meios de comunicação de massa (Modern Ideology and Culture: Critical Social Theory in the Age of Mass Media). Retrieved from https://bit.ly/2Hjajge. 
